\title{
R. J. Maneksha - The human face of Indian Plastic Surgery
}

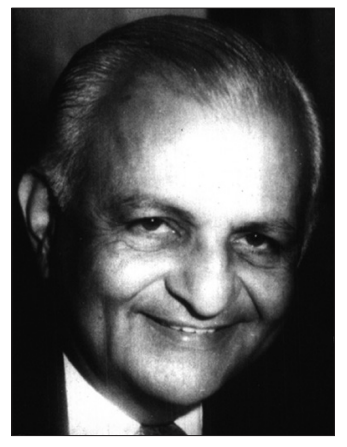

Dr. Rustom Maneksha
"It is good to hark back to the olden days and gratefully to recall the men whose labours in the past have made the present possible."

Osler, William, Aequanimitas

Dr. Rustom Jamshed Maneksha aka Rusi Maneksha (1919-2004) was a pioneering surgeon who visualised the importance of the speciality, plastic surgery, went abroad to train under giants in the field and returned to India to practice and teach the speciality.

Born on 14 February 1919 in Mumbai, India, he was the second of three children of Dr. Jamshed Maneksha, a general practitioner, and Mrs. Goolbai Maneksha. His elder sister Rupy, married Goody Seervai, the famous band leader, and the younger brother, Manek, was a physician, who settled in England.

He studied at Bharda New High School and St. Xavier's College and graduated from Grant Medical College Mumbai as a physician in 1944. He trained at Bart's and the North Middlesex Hospitals in London and got his FRCS (Eng.) degree in 1946 before returning to India in the late 40 s, carrying with him a keen interest in the relatively new field of Plastic Surgery. Later on, he got his FACS (USA) and also became an FICS.

In April 1946, he married Roda Nadir Reporter, by whom

\begin{tabular}{|l|l|}
\hline \multicolumn{3}{|c|}{ Access this article online } \\
\hline Quick Response Code: & Website: \\
& www.ijps.org \\
\cline { 2 - 2 } & DoI: \\
\hline
\end{tabular}

he had two sons, Jimmy who is presently a cardiothoracic surgeon and Farrokh who is an anaesthesiologist in the USA. "Mom was very religious and was supportive and protective towards dad. She dedicated herself to raising us and looking after the house so dad did not have to bother with this. She looked after all the finances and the day to day running of the house. Mom and Dad had a happy married life." - sentiments of the two sons, Jimmy and Farrokh.

Dr. Maneksha had a keen interest in sports, playing cricket and table tennis in his younger days. He captained his college teams and was a regular in the various Doctors vs. Lawyers and other such matches through the years. He was a very good batsman and also a great lefty spin bowler. His last performance was in 1986.

He got into golfing at a late age and took it up seriously at the Willingdon Sports Club. He would always start off his days at 6:30 a.m., teeing off with his golfing buddies. He continued to play golf till the early 90 s despite a posttrauma painful foot with an arch collapse. In his words, "Doing Plastic Surgery can be compared very much to playing golf! Incidentally both bring out the best in you. On the golf course you plan each hole in advance after due study, then start on the tee after selecting the proper club, try to avoid all the hazards and if entrapped overcome them and finally reaching the undulating putting green reach the final goal..."

He was appointed as a general surgeon at Gokuldas Tejpal Hospital, Mumbai, which is a teaching hospital. In his words, "I am deeply grateful to Dr. R. G. Talwalkar, F.R.C.S., with whom I have been associated since 1949 and who allowed me unlimited scope to develop this branch of surgery." While attached to the General Surgery 
unit, he continued to selectively perform plastic surgical operations.

Promotion of the speciality in India was included in the "Colombo Plan" and Dr. Maneksha did his share in the success. He had a special enthusiasm for cleft lip and palate surgery. He established and headed the unit of plastic surgery at GT Hospital in 1964 till he retired in 1975. He trained a number of postgraduate students here and at Poddar Hospital.

He treated a large number of young people having smallpox scars on the face. This led him to design the manual metallic dermabrader in 1950 .

In 1958, he started the Plastic Surgery Department at Bombay Hospital. He was also on the faculty of the Central Railway Hospital and Jagjivan Ram Hospital (Railway) at their initiation.

In 1976, he was honoured with the title of Surgeon Commodore by the President of India for his significant contribution at the Armed Forces Hospital INHS Asvini, treating the wounded from the 1965 and 1971 Indo-Pak war. This included a significant bulk of burn cases. His services were also used for the treatment of other plastic surgical cases as there were only a few plastic surgeons in the country at that time.

He operated at Bachha, Sodha, and Northcote Nursing Homes and Cumballa Hill Hospital. He was also a visiting surgeon at Dubai.

He conducted lectures for general practitioners to increase awareness about this upcoming field. His articles appeared in various magazines. He had a very varied practice including a significant bulk of cosmetic surgical cases. In his words, "Although cosmetic surgery is critical in elevating the patients' quality of life, it can be degraded by repugnant advertising and marketing.... It can be considered the loftiest form of surgery that treats the very soul of the patient. It is for very good reasons that the plastic surgeon has been termed "a psychiatrist with the scalpel' by Joseph Murray." He designed a set of mannual dermabraders [Figure 1] which are still available and widely used.

He kept abreast with new developments through latest books and periodicals and by attending and presenting his work at national and international conferences. He would either visit or invite persons describing new techniques and learn them from the horse's mouth, so to say. He would also procure the necessary newly designed instruments and implants to perform the procedures and encouraged others to use them too. He visited various centres in Britain. He obtained firsthand knowledge from a number of eminent plastic surgeons from all over the globe: Sir Archibald McIndoe, Tord Skoog, Sir Harold Gillies, Sir Benjamin Rank, Rainsford Mowlem, Bengt Johansen, Dr. Paul Tessier, Yves Gerard Illouz, Eric Peet, Obwegeser Tokvam, to name a few, and developed and maintained a good relationship. Many prominent plastic surgeons visited India and stayed with him.

The wisdom of Sir William Osler's book, Aecquinimitas, had left an indelible mark on him. He was very well read. When dealing with patients, he believed in Dr. Frank Spencer's attitude which was a blend of confident optimism with pragmatic realism. His interaction with the patient was directed towards engendering faith and hope and minimising pain and fear. He agreed with Eisenberg's saying, "The two basic pleasures of medicine are the treatment of the ill patient and the intellectual challenge of solving clinical problems, not the income earned." Throughout his career, he practiced these doctrines. He was always considerate of the patients' affordability and available to all economic strata.

He was prompt in gleaning the latest advances, but he followed what he quoted from Sir Hutchinson, "Protect yourself from too much zeal for the new and contempt for what is old, from putting knowledge before wisdom, science before art, from treating patients as cases and from making the cure more grievous than the illness." He also wrote, "The occurrence of major changes, per se, is obviously not a cause for gloom and pessimism.... Scientific progress has been incredible yet the ... stature of medicine seemed considerably greater in the times of Osler than it does at present. ... Osler realized that illness produces an abnormally sensitive emotional state.... The treatment of disease is scientific; the treatment of the human being has been termed humanism, often called the art of medicine. Scientific medicine with little or no humanism is impersonal and cold. Humanism makes it a profession rather than a business or a trade."

He as very jovial, fun loving, good natured and soft spoken person. He was co-operative, adjusting, very patient, and 


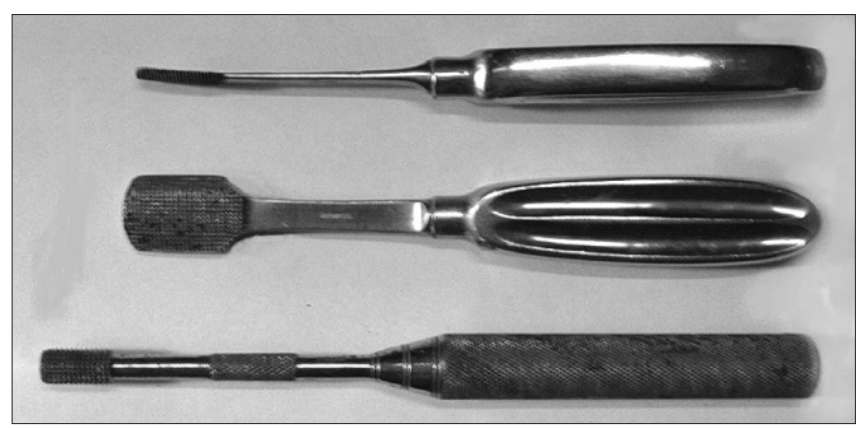

Figure 1: Manual dermabraders designed by Dr. R. J. Maneksha

punctual, and his surgery was precise with no wastage of intra-operative time. He was a thorough gentleman.

and was respected by all. He had a good rapport with all his medical colleagues and got a vast variety of referrals. He welcomed the opinion of juniors and encouraged discussions when planning any surgery. He also encouraged them to write articles using his cases.

He saw good in everyone and always tried to promote people. Those working with him made a sincere effort to live up to his expectations. He had an honest, expressive face and never raised his voice in anger. His expression of dissatisfaction was sufficient to make anyone wish he or she could withdraw into a turtle shell. He never held any grudges. Even today, the more senior operation theatre assistants who have worked with him compare the behaviour of consultants to what they consider to be the "Gold Standard" laid down by him.

He took active part in organising various very successful and well-attended national and international conferences and was the President of the Association of Plastic Surgeons of India (APSI) for two consecutive years, from 1970 to 1972 , due to the war.

He maintained photographic records of his cases right from the start and authored two well-illustrated books, "Plastic Surgery in the Tropics, 1965" and "Colour Atlas of Cleft Lip Surgery, 1986." He was an internationally recognised figure in the world of plastic surgery. His earlier articles were on general surgery topics and appeared in "Antiseptic" from 1948. His articles in the speciality appeared in Plastic and Reconstructive Surgery in 1960 and 1963, and British Journal of Plastic Surgery in 1961. He wrote the foreword in Tokvam, O., MaxilloFacial Injuries 1965, and authored a chapter in Surgical Rehabilitation in Leprosy by McDowell, F. and Enna, C. D. 1974. His letter is included in Millards Cleft Craft (1976). He was an International Reviewer - Cleft Palate Journal (USA).

He loved classical music, especially Mozart, and he played the violin from a young age. He was a member of the Bombay Symphony Orchestra under the baton of Mehli Mehta. His son Farrokh studied the piano for a while and they would often play together in the evenings. "When he came home from work to have lunch, he would often ask me to put on some nice classical music on the gramophone and he would relax with that. He also listened to some popular music of the time, such as Nat King Cole, Frank Sinatra, Pat Boone, Maurice Chevalier, etc." - Farrokh

He began weaning his practice in 1993 and continued as Consultant Emeritus. His interest in golf and his social life kept him busy. However, in 1997, Roda's demise left him heartbroken. He breathed his last at Bachha Nursing Home on 6 June 2004. With his passing away, we have lost one of our earliest pioneers who contributed to the re-birth of plastic surgery in India. It was an honour to have him in this speciality to which he gave so much respectability by his very presence.

Words written for W. Osler truly apply to Dr. Maneksha as well: "He had a love of the history of our profession as shown in the writings of its masters, as well as a love of general literature. ... His way of life was to live each day out and to take no thought of the morrow."

Kumkum J. Khadalia Consultant Plastic Surgeon, Bombay Hospital, Mumbai. Email: kumkhadalia@gmail.com

How to cite this article: Khadalia KJ. R. J. Maneksha - The human face of Indian Plastic Surgery. Indian J Plast Surg 2011;44:377-9. 